is obstructed by swelling of the mucosa it may be of benefit to blow oxygen on the obstructed part. It is safe to say that we became more and more conservative in regard to bronchoscopy as time went on, the general impression being that the amount of secretions increases after bronchoscopy. Tapotement and "squeezing" of the thorax seemed to have much greater effect, especially if suction from the bronchi was done simultaneously. Frequent changes in position are also of importance, to avoid atelectasis.

\section{Problems of Organization}

Previous to this epidemic no anaesthetist had ever worked regularly at the fever hospital. Now we were suddenly faced with the problem of recruiting a minimum of 40 persons trained in anaesthesiology who could cover the following field of work: (1) anaesthesia for the tracheotomies ; (2) ventilation of tracheostomized patients; (3) cleaning of the lungs, treatment of atelectasis ; and (4) treatment of shock. It took us only a few days to find that this work could not possibly be covered by the already functioning personnel without help from outside on a large scale. At one time during the epidemic, when 900 poliomyelitis patients had already been admitted, 75 patients were under manual artificial ventilation on the same day. For this it was necessary to employ 250 medical students to do the ventilation, 260 nurses from outside to sit at the bedside and attend to the patients' requirements, and 27 hospital workers to change cylinders and control the machinery: within these 24 hours 250 10-gallon (45.5-litre) cylinders were used.

The working plan of the anaesthetists was this. Each of the four big hospitals (the University Hospital, the Municipal Hospital, the Bispebjerg Hospital, and the County Hospital) covered a 24-hour period with its anaesthesia staff, under the direction of the senior anaesthetist, who spent the full period in the fever hospital. He did the anaesthesia and supervised his assistants. The latter, together with the epidemiologists and the otologists, supervised the medical students. Usually there was one anaesthetist in each of the three wards where the patients with respiratory and pharyngeal paralysis were treated. The anaesthesia staffs of the other Copenhagen hospitals (Finsen Institute, Orthopaedic Hospital, Municipal Chest Hospital) formed a very useful reserve.

At a relatively early stage it was decided to have lung physiotherapists working with selected patients who were apt to develop repeated atelectases. This arrangement proved very successful, and a total of 34 physiotherapists were active during the period of the epidemic. As previously mentioned, the procedure seemed most beneficial when physiotherapist and anaesthetist worked together.

It would take too long to go into details regarding the organization of the other groups of personnel. The organization and distribution of the patients were briefly mentioned in the introduction.

\section{Technical Problems}

When news about the epidemic had spread in Copenhagen equipment of all kinds poured into the hospital in a steady stream. It was soon found necessary to co-ordinate all these different types of material and also make an attempt to standardize the equipment. For this reason one man (an engineer) was appointed as consultant to the hospital. All requisitions went through him, and he, on the other hand, promised to procure the items with no delay. This system turned out to be a very good one.

The different types of respirator were supplied by various firms. A large number were borrowed from the other Scandinavian countries.

Equipment Around a Patient Under Manual Artificial Ventilation.-Oxygen cylinder with nitrogen and oxygen in $50 \%$ mixture. Reducing valve and flowmeter. Compressedair cylinder with regulator, and injector suction aggregate. To-and-fro system (see Diagram) with two canisters and bag.
A special problem is the soda-lime for the canisters. Most preparations contain too much dust and present a potential danger of blowing dust into the patient's lungs. Actually only two preparations were suitable for use in this kind of treatment. Another problem was that the stores of sodalime in Denmark were much too small to cover the demand, and we had to send for help from Great Britain, Sweden, and Norway several times: we got the help very promptly. It is estimated that about 100,000 blood-pressure measurements were taken during the five months, and there had to be a large number of B.P. cuffs in the hospital.

Anaesthetic Equipment.-Two anaesthetic machines, transportable, with suction; laryngoscopes with two blades; tracheal tubes in all sizes, with and without cuff ; introducer for tubes ; masks in three sizes ; extra reservoir bags; airways of all sizes; suction catheters of different types with glass connexions; and stomach tubes. All equipment was kept in the operating-room, and was packed on trays and in boxes for immediate use in any part of the hospital where tracheostomies might have to be done. Furthermore, in each of the three wards an emergency set with equipment for manual intermittent positive-pressure ventilation and for intubation was kept. Finally, the admission ward was equipped with the previously mentioned complete set for the team which would go out to the provincial hospitals.

\section{Conclusion}

This report is an attempt to answer-some of the questions of practical interest to those who will be concerned with the treatment of a large group of patients with poliomyelitis and respiratory and/or pharyngeal paralysis under emergency conditions. We have omitted the theoretical deliberations, which will all be found in the report under preparation and also in the paper which follows.

BIBLIOGRapHy

Astrup, P., et al. (1954). British Medical Journal, 1, 780. Lassen, H. C. A. (1953). Lancet, 1, 37.

\section{EFFECT OF PHENYLBUTAZONE ON URIC ACID METABOLISM}

BY

\section{Consulting Physician, Department of Physical Medicine, Chase Farm Hospital}

Phenylbutazone ("butazolidin") has been said to be effective both in acute gout and in the later chronic stages. Amongst the varied clinical effects of this drug such claims stand out as of particular interest. Kuzell and his colleagues (1952) found that it had "a marked analgesic effect" on the acute attack within a few minutes, and other workers have confirmed this (Kidd et al., 1952). There is, however, considerable disagreement about its effect, if any, on uric acid metabolism itself. Most workers are agreed that lowered blood uric acid levels follow the administration of phenylbutazone. Kuzell et al. claimed a "striking diminution of serum uric acid in all patients treated," without, however, putting forward any data. There followed the interesting suggestion that this lowering of blood levels was not associated with a comparable increase in uric acid excretion in the urine (Kuzell and Schaffarzick, 1952 ; Engleman, 1952). Kersley et al. (1953), studying 14 cases of rheumatoid arthritis treated with phenylbutazone, could find no change in uric acid excretion, although they noted sodium retention. On the other 
hand, Smyth (1953) found a rise in the urinary excretion and a fall in plasma uric acid levels in a single case, and Bowers (1953) reported a death following phenylbutazone therapy in a gouty subject, in whom both ureters were found at necropsy to be blocked with uric acid crystals.

The published data on which these observations are based are relatively scanty, for opportunities of carrying out the necessary in-patient studies on patients with an essentially episodic disease are rare, especially if observations are needed during the interval rather than during the acute attack.

If phenylbutazone has a specific effect on uric acid metabolism and on acute gout this would be unique, for it would differ from that of other known drugs. Colchicine, which is effective in the acute attack, has no known effect on blood levels. The uricosuric drugs, such as salicylates, cinchophen, or probenicid (" benemid"), which lower blood levels by producing a uric acid diuresis, have never been found effective for the acute attack, apart from the analgesic effect of the first two. Probenicid, moreover, often precipitates an acute attack. Cortisone and A.C.T.H. have, of course, a uricosuric effect which is well documented (Thorn et al., 1950 ; and many others), but this may be unrelated to their mode of action in relieving acute gout.

The suggestion that phenylbutazone lowers blood levels at the same time as it relieves the acute attack

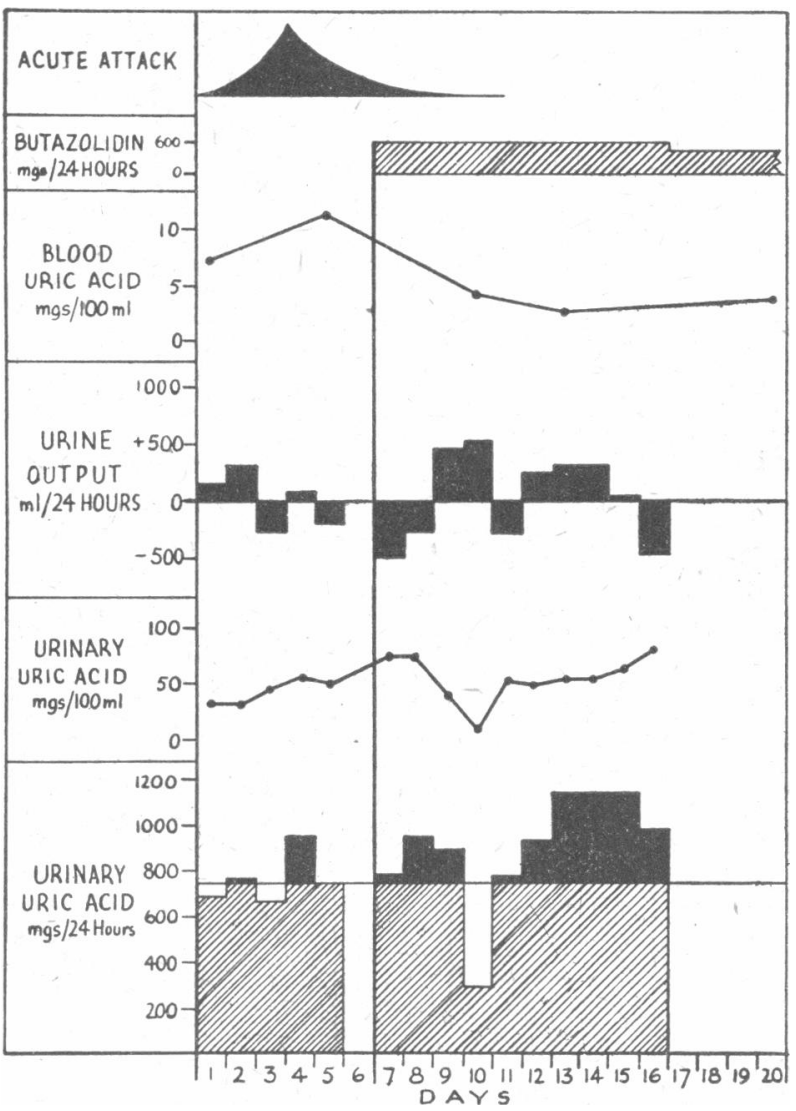

FIG. 1.-Chart of Case 1

and that this is not accompanied by a comparable uricosuric effect deserves careful study. If this were true it might follow that phenylbutazone has some effect on uric acid metabolism itself. Such an effect, it must be recognized, would be coincidental to its mode of action in rheumatoid arthritis and other rheumatic conditions, and apart from its constant sodium-retaining effect (Green and Williams, 1953).

The following observations represent an attempt to throw some light on these possibilities by studying the effect of phenylbutazone on blood uric acid levels and urinary uric acid excretion at the same time in four cases of gout and one control patient.

\section{Case 1}

A man aged 63 had had episodic gout of six years' duration without formation of tophi. In addition, he had had three attacks of coronary thrombosis and there was evidence of renal impairment, his blood urea being $57 \mathrm{mg}$. per $100 \mathrm{ml}$.

TABLE I.-Means of Uric Acid Estimations on Case 1, Treated with Phenylbutazone $600 \mathrm{mg}$./day for 10 Days

\begin{tabular}{|c|c|c|c|c|c|}
\hline Day & $\begin{array}{c}\text { Vol. } \\
\text { Urine } \\
\text { (ml. } / 24 \mathrm{hrs} \text { ) }\end{array}$ & $\begin{array}{c}\text { Urinary } \\
\text { Uric Acid } \\
\text { (mg. } / 24 \text { hrs.) }\end{array}$ & $\begin{array}{c}\text { Excess Urinary } \\
\text { Uric Acid } \\
\text { Excretion } \\
\text { (mg. } / 24 \text { hrs.) }\end{array}$ & $\mid \begin{array}{c}\text { Blood } \\
\text { Uric Acid } \\
\text { (mg./100 ml.) }\end{array}$ & $\begin{array}{l}\begin{array}{l}\text { Phenyl- } \\
\text { butazone }\end{array} \\
\text { (mg./ } \\
24 \mathrm{hrs} .)\end{array}$ \\
\hline $\begin{array}{r}1-5 \\
7-11 \\
12-16\end{array}$ & $\begin{array}{l}1,660 \\
1,677 \\
1,761\end{array}$ & $\begin{array}{r}743 \\
727 \\
1,056\end{array}$ & $\begin{array}{l}-16 \\
+313\end{array}$ & $\begin{array}{l}9.4 \\
4.3 \\
3.0\end{array}$ & $\begin{array}{l}600 \\
600\end{array}$ \\
\hline
\end{tabular}

Total excess uric acid excreted days $7-16=1,485 \mathrm{mg}$.

and his urea clearance $48 \%$ of average normal function. His blood pressure was $180 / 100 \mathrm{~mm}$. Hg. Unfortunately, he had an acute attack during the control period, during which the blood uric acid rose from 7.2 to $11.6 \mathrm{mg}$. per $100 \mathrm{ml}$. (Fig. 1).

On the seventh day of observation phenylbutazone, 600 mg. a day by mouth, was started. On the following day joint tenderness was much diminished, although whether this was due to the phenylbutazone or to the natural termination of the attack it was not possible to say. A sharp fall in blood uric acid levels was observed from $11.6 \mathrm{mg}$. on day 5 , before treatment, to $4.3 \mathrm{mg}$. per $100 \mathrm{ml}$. on day 10 (Table I). During this period there seems to have been only a small excess excretion of uric acid, amounting to a total of $360 \mathrm{mg}$. only. This is just the sort of phenomenon described by some previous workers. During the second five days of treatment, how e ver, there was a moderate diuresis of uric acid. During the first two days there was a slight diminution in water output, with a rise in urinary uric acid concentration from a pretreatment mean of 45 mg. (maximum $53 \mathrm{mg}$.)

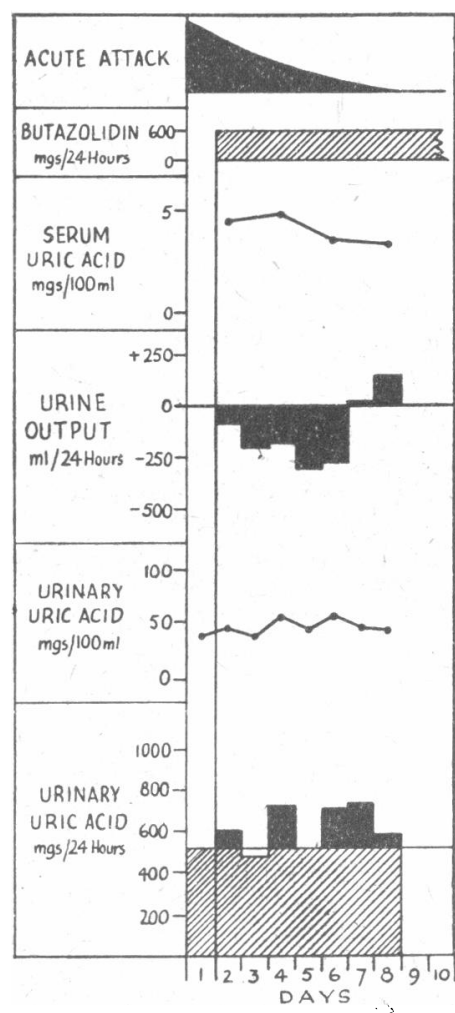

Fig. 2.-Chart of Case 2 . to a mean of $66 \mathrm{mg}$. per $100 \mathrm{ml}$., so that despite the fall in water output an actual excess of uric acid excretion occurred. During the second five days of treatment the mean urinary uric acid concentration was $62 \mathrm{mg}$. per $100 \mathrm{ml}$., and a total excess of uric acid excretion during the whole period of treatment, 10 days, amounted to $1,485 \mathrm{mg}$. 


\section{Case 2}

This is a brief study of a man aged 52 giving a five-years history of episodes of acute gout occurring once a year until the previous year, during which he had had five attacks. He was admitted with a severe polyarticular attack in the big toe, both knees, and one elbow. Renal function showed a slight impairment, his blood urea being $34 \mathrm{mg}$. per $100 \mathrm{ml}$. and urea clearance $69 \%$ of average normal function. Urinary concentration was to a maximum specific gravity of 1020.

On admission his attack was beginning to subside, although the big-toe joint and elbow were extremely tender. Only one control day was available. His attack settled during treatment with phenylbutazione (Fig. 2), although the patient himself was unimpressed with the rate of subsidence and considered it to be at a normal rate. Some water retention occurred, the urinary volume being diminished from a control $1,570 \mathrm{ml}$. to $1,366 \mathrm{ml}$. per 24 hours (Table II). Urinary uric acid concentration rose from $34 \mathrm{mg}$.

TABle II.-Means of Uric Acid Estimations in Case 2, Treated with Phenylbutazone $600 \mathrm{mg}$./day for Seven Days

\begin{tabular}{|c|c|c|c|c|c|}
\hline Day & $\begin{array}{c}\text { Vol. } \\
\text { Urine } \\
\text { (ml. } / 24 \mathrm{hr} \text {.) }\end{array}$ & $\begin{array}{c}\text { Urinary } \\
\text { Uric Acid } \\
\text { (mg./24 hr.) }\end{array}$ & $\begin{array}{c}\text { Excess Urinary } \\
\text { Uric Acid } \\
\text { Excretion } \\
\text { (mg./24 hr.) }\end{array}$ & $\begin{array}{c}\text { Serum } \\
\text { Uric Acid } \\
\text { (mg./100 ml.) }\end{array}$ & $\begin{array}{l}\text { Phenyl- } \\
\text { butazone } \\
\text { (mg./ } \\
24 \text { hr.) }\end{array}$ \\
\hline $\begin{array}{c}1 \\
2-6 \\
7-8\end{array}$ & $\begin{array}{l}1,570 \\
1,366 \\
1,495\end{array}$ & $\begin{array}{l}535 \\
616 \\
668\end{array}$ & $\begin{array}{r}+\overline{81} \\
+133\end{array}$ & $\begin{array}{l}4 \cdot 7 \\
4 \cdot 2 \\
3 \cdot 5\end{array}$ & $6 \overline{600}$ \\
\hline
\end{tabular}

Total excess uric acid excreted days $2-8=671 \mathrm{mg}$.

to a mean of $45.2 \mathrm{mg}$. per $100 \mathrm{ml}$. (maximum $55 \mathrm{mg}$. per $100 \mathrm{ml}$.). The total excess of uric acid excreted during the first seven days amounted to $620 \mathrm{mg}$., and during this period the serum uric acid fell from $4.7 \mathrm{mg}$. to $3.5 \mathrm{mg}$. per $100 \mathrm{ml}$.

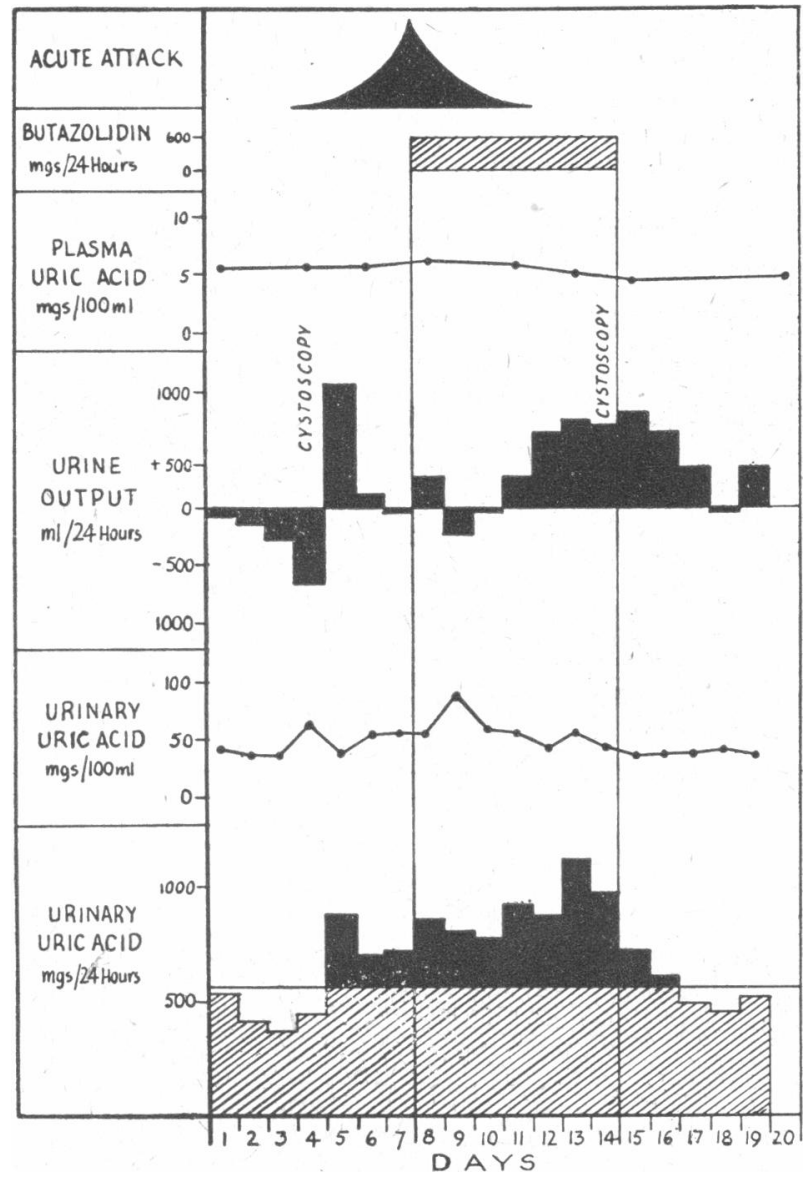

Fis. 3.- Chart of Case 3.
In this case, therefore, despite water retention, the increased concentration of urinary uric acid was sufficient to permit an excess of uric acid to be excreted.

Case 3

A man aged 76 had had attacks of gout for the previous fifteen years. No tophi had developed. During the control period there was an unsuccessful cystoscopy which was followed on the next day by an attack of gout. Again, the clinical response was satisfactory but not remarkable. There was a slight fall of plasma uric acid levels from 5.4 mg. per $100 \mathrm{ml}$. during the control period (three readings) to $5 \mathrm{mg}$. on the sixth day of treatment, and to $4.6 \mathrm{mg}$. on the day after completion of one week on phenylbutazone, $600 \mathrm{mg}$. a day (Fig. 3). A water diuresis occurred during the latter part of treatment and the urinary uric acid concentration rose from a mean of $47 \mathrm{mg}$. per $100 \mathrm{ml}$. (maximum $65 \mathrm{mg}$.) to a mean of $57 \mathrm{mg}$. (maximum $77 \mathrm{mg}$.) during treatment. The total excess of uric acid excreted amounted to $2,254 \mathrm{mg}$. (Table III). In this case, therefore, quite a marked uricosuric action is observed under conditions where water retention did not appear to occur.

TABLE III.-Means of Uric Acid Estimations in Case 3, Treated with Phenylbutazone $600 \mathrm{mg}$./day for Seven Days

\begin{tabular}{|c|c|c|c|c|c|}
\hline Day & $\begin{array}{l}\text { Vol. } \\
\text { Urine } \\
\text { (ml. } / 24 \text { hr.) }\end{array}$ & $\begin{array}{c}\text { Urinary } \\
\text { Uric Acid } \\
\text { (mg./24 hr.) }\end{array}$ & $\begin{array}{c}\text { Excess Urinary } \\
\text { Uric Acid } \\
\text { Excretion } \\
\text { (mg./24 hr.) }\end{array}$ & $\begin{array}{c}\text { Plasma } \\
\text { Uric Acid } \\
\text { (mg. } / 100 \mathrm{ml} .)\end{array}$ & $\begin{array}{c}\text { Phenyl- } \\
\text { butazone } \\
\text { (mg.) } \\
24 \mathrm{hr} \text {.) }\end{array}$ \\
\hline $\begin{array}{c}1-7 \\
8-14 \\
15-19\end{array}$ & $\begin{array}{l}1,291 \\
1,631 \\
1,730\end{array}$ & $\begin{array}{l}580 \\
902 \\
568\end{array}$ & $\begin{array}{r}\overline{322} \\
-12\end{array}$ & $\begin{array}{l}5.4 \\
5.6 \\
4.8\end{array}$ & 600 \\
\hline
\end{tabular}

Total excess uric acid excreted days $8-14=2,254 \mathrm{mg}$.

\section{Case 4}

This patient was a man aged 81 with severe chronic tophaceous gout. It was possible in this case to compare the action of phenylbutazone with a known uricosuric agent, probenicid. It can be seen from Fig. 4 that their actions were in this case somewhat different; phenylbutazone was followed by water retention, and the rise in the concentration of urinary uric acid was not quite sufficient to. overcome this, so that although the concentration rose from $46 \mathrm{mg}$. to $79 \mathrm{mg}$. per $100 \mathrm{ml}$. (maximum $91 \mathrm{mg}$.), there was in

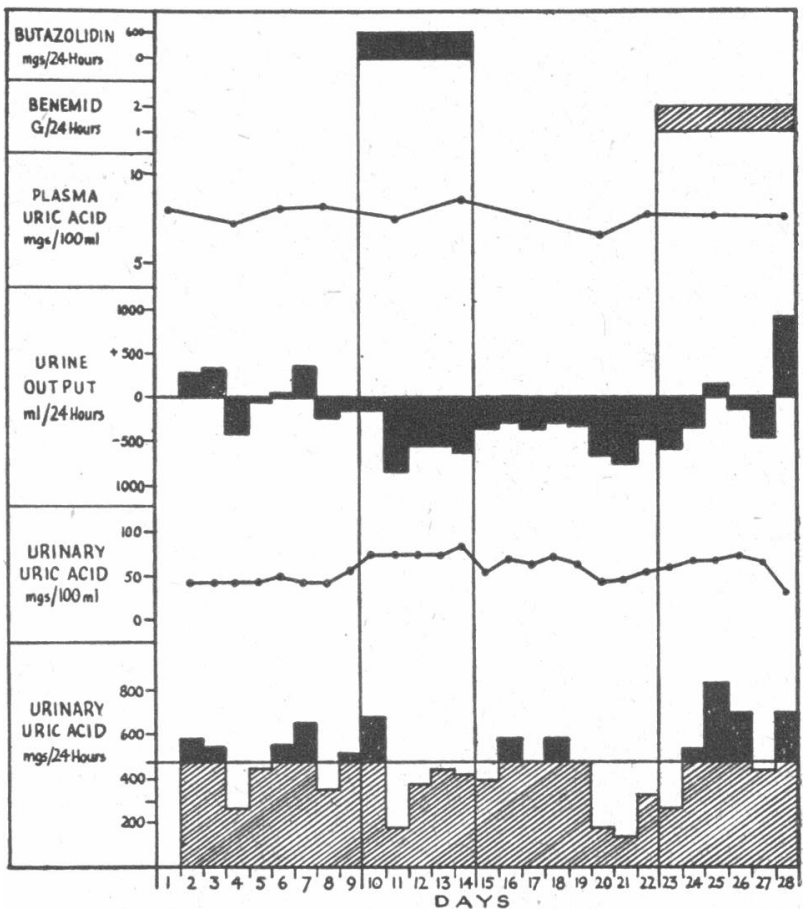

Fio. 4.- Chart of Case 4. 
fact a net retention of uric acid amounting to $365 \mathrm{mg}$. At the same time, 2.7 litres of water was retained and the rate of urine output fell below $1 \mathrm{ml}$. a minute. This water retention became persistent, although the output returned to control values during probenicid administration (Table IV),

TABLE IV.-Means of Uric Acid Estimations in Case 4, Treated with Phenylbutazone $600 \mathrm{mg}$./ day for Five Days and with Probenicid 2 g./day for Six Days

\begin{tabular}{|c|c|c|c|c|c|c|}
\hline Day & $\begin{array}{l}\text { Vol. } \\
\text { Urine } \\
\text { (ml./ } \\
24 \mathrm{br} .)\end{array}$ & $\begin{array}{c}\text { Urinary } \\
\text { Uric } \\
\text { Acid } \\
\text { (mg./ } \\
24 \mathrm{hr} .)\end{array}$ & $\begin{array}{c}\text { Excess } \\
\text { Urinary } \\
\text { Uric Acid } \\
\text { Excretion } \\
\text { (mg. } / 24 \mathrm{hr} \text {.) }\end{array}$ & $\begin{array}{c}\text { Plasma } \\
\text { Uric } \\
\text { Acid } \\
\text { (mg./ } \\
100 \mathrm{ml} .)\end{array}$ & $\begin{array}{c}\text { Phenyl- } \\
\text { butazone } \\
\text { (mg./ } \\
24 \mathrm{hr} \text {.) }\end{array}$ & $\begin{array}{l}\text { Probenicid } \\
\text { (g. } / 24 \mathrm{hr} \text { ) }\end{array}$ \\
\hline $\begin{array}{c}1-9 \\
10-14 \\
15-22 \\
23-28\end{array}$ & $\begin{array}{r}1,069 \\
524 \\
643 \\
998\end{array}$ & $\begin{array}{l}483 \\
410 \\
396 \\
580\end{array}$ & $\begin{array}{l}-73 \\
-87 \\
+97\end{array}$ & $\begin{array}{l}7.9 \\
8.1 \\
7.2 \\
7.8\end{array}$ & 흐 & $\overline{\bar{z}}$ \\
\hline
\end{tabular}

Total retention of uric acid during phenylbutazone therapy (days 10-14) $365 \mathrm{mg}$. Total excess excretion of uric acid during probenicid therapy (days $23-28)=582 \mathrm{mg}$.

and this, combined with an increased concentration of uric acid in the urine, allowed a net excess of uric acid amounting to $582 \mathrm{mg}$. to be excreted in six days, but a total water retention amounting to 6.5 litres appears to have occurred during the period of study. Ten days later the patient developed congestive heart failure; treatment with digoxin then led to a fall in weight from $10 \mathrm{st}$. $6 \mathrm{lb}$. to $8 \mathrm{st} .8 \mathrm{lb}$. (66.2 to $54.4 \mathrm{~kg}$.), this being equivalent to 12 litres of water.

It can be well understood that body-fluid changes of this nature must influence plasma uric acid and urinary uric acid findings considerably, and must be taken into account. Great care is necessary before making any assumptions from investigations of this kind whether uric acid metabolism is being affected or whether the uricosuric action of phenylbutazone is sufficient to account for the changes observed.

Do non-gouty patients behave in a different manner from gouty patients? The main indication for phenylbutazone is pain unrelieved by aspirin, and, unfortunately. aspirin has a mild uricosuric effect, so that a pure picture is not readily obtainable from such cases. It has, however, been possible to study one patient in detail.

\section{Case 5}

This patient had Paget's disease, causing severe pain, which was relieved to a very real extent by phenylbutazone. Water retention did not occur here (Fig. 5 ; Table $\mathrm{V}$, and there was a slight rise in the urihary acid concentration from a mean of $30 \mathrm{mg}$. per $100 \mathrm{ml}$. (maximum $35 \mathrm{mg}$.) to $34 \mathrm{mg}$. (maximum $42 \mathrm{mg}$.), and a small excess of uric acid was excreted with an associated drop in plasma uric acid levels. During the first week of phenylbutazone adminis. tration an excess of $686 \mathrm{mg}$. was excreted, the plasma uric acid falling from 4.9 to 2.6 and later to $2.3 \mathrm{mg}$. per $100 \mathrm{ml}$.
TABle V.-Means of Uric Acid Estimations in Case 5 Treated with Phenylbutazone $600 \mathrm{mg}$./day for 16 Days

\begin{tabular}{|c|c|c|c|c|c|}
\hline Day & $\begin{array}{c}\text { Vol. } \\
\text { Urine } \\
\text { (ml. } / 24 \text { hr.) }\end{array}$ & $\begin{array}{c}\text { Urinary } \\
\text { Urí Acid } \\
\text { (mg./24 hr.) }\end{array}$ & $\begin{array}{l}\text { Excess Urinary } \\
\text { Uric Acid } \\
\text { Excretion } \\
\text { (mg./24 hr.) }\end{array}$ & $\begin{array}{c}\text { Plasma } \\
\text { Uric Acid } \\
\text { (mg. } / 100 \mathrm{ml} .)\end{array}$ & $\begin{array}{c}\text { Phenyl- } \\
\text { butazone } \\
\text { (mg.l } \\
24 \text { hr.) }\end{array}$ \\
\hline $\begin{array}{c}1-5 \\
6-12 \\
13-21 \\
22-31 \\
32-35\end{array}$ & $\begin{array}{l}1,966 \\
1,993 \\
2,454 \\
2,778 \\
2,505\end{array}$ & $\begin{array}{l}568 \\
666 \\
628 \\
598 \\
760\end{array}$ & $\begin{array}{r}\overline{+} \\
+98 \\
+60 \\
+30 \\
+192\end{array}$ & $\begin{array}{l}4 \cdot 7 \\
3 \cdot 3 \\
2 \cdot 4 \\
3 \cdot 2 \\
4 \cdot 5\end{array}$ & $\begin{array}{l}\overline{600} \\
600 \\
6 \overline{600}\end{array}$ \\
\hline
\end{tabular}

Total excess uric acid excreted days $6-21=1,226 \mathrm{mg}$.

\section{Discussion}

These studies suggest that phenylbutazone has a fairly constant, if slight, uricosuric effect. In four of the five cases an excess of uric acid excretion occurred during the period of drug administration, and in the one case in which it did not occur water retention was enough to precipitate congestive heart failure following an observed retention of 6.5 litres of water. This effect, if it exists, is, however, insufficient to be demonstrable statistically on the data available. No advantage would seem to be offered by pursuing this aspect of the investigation further, although these observations would enable a suitable experiment to be designed to establish this.

Is it possible to assess whether in fact the fall in circulating uric acid level is greater than that which could be anticipated on the basis of excretion studies ? If one assumes that the total body fluid equals 0.7 of body weight (Benedict $e t$ al., 1950) and that uric acid is equally distributed throughout the body fluids, then it is possible to calcu-

TABLE VI.-Calculated Changes in Total Body Uric Acid Compared with Actual Excess Uric Acid Excreted During Phenylbutazone Administration

\begin{tabular}{|c|c|c|c|c|c|c|c|c|c|c|}
\hline $\begin{array}{l}\text { Case } \\
\text { No. }\end{array}$ & $\begin{array}{c}\text { Weight } \\
\text { (kg.) }\end{array}$ & $\begin{array}{l}\text { Body } \\
\text { Water } \\
\text { (litres) }\end{array}$ & $\begin{array}{c}\text { Plasma } \\
\text { Uric Acid } \\
\text { (mg. } / 100 \mathrm{ml} .)\end{array}$ & $\begin{array}{c}\text { Total Body } \\
\text { Urate } \\
\text { Before } \\
\text { Treatment } \\
\text { (mg.) }\end{array}$ & $\begin{array}{c}\text { Days } \\
\text { Treated }\end{array}$ & $\begin{array}{c}\text { Plasma } \\
\text { Uric Acid } \\
\text { After } \\
\text { Treatment } \\
\text { (mg./100 ml.) }\end{array}$ & $\begin{array}{l}\text { Total Body } \\
\text { Urate } \\
\text { After } \\
\text { Treatment } \\
\text { (mg.) }\end{array}$ & $\begin{array}{c}\text { Calculated } \\
\text { Loss of } \\
\text { Body Uric } \\
\text { Acid } \\
\text { (mg.) }\end{array}$ & $\begin{array}{l}\text { Excess } \\
\text { Uric } \\
\text { Acid } \\
\text { Excreted } \\
\text { (mg.) }\end{array}$ & $\begin{array}{c}\text { Discrepancy } \\
\text { (mg.) } \\
\text { (Urinary Excess } \\
\text { - Calculated } \\
\text { Change) }\end{array}$ \\
\hline $\begin{array}{l}1 \\
2 \\
3 \\
5\end{array}$ & $\begin{array}{r}75.5 \\
70.0 \\
104.5 \\
57.3\end{array}$ & $\begin{array}{l}52.9 \\
49.0 \\
73.2 \\
40.1\end{array}$ & $\begin{array}{l}9 \cdot 4^{*} \\
4 \cdot 9 \\
5 \cdot 4 \\
4 \cdot 7\end{array}$ & $\begin{array}{l}4,973 \\
2,401 \\
3,953 \\
1,885\end{array}$ & $\begin{array}{r}6 \\
6 \\
5 \\
14\end{array}$ & $\begin{array}{l}3.0^{*} \\
3 \cdot 5 \\
5 \cdot 0 \\
2 \cdot 3\end{array}$ & $\begin{array}{r}1,587 \\
1,71 \cdot 5 \\
3,660 \\
922\end{array}$ & $\begin{array}{r}3,386 \\
686 \\
293 \\
963\end{array}$ & $\begin{array}{r}483 \\
620 \\
805 \\
1,050\end{array}$ & $\begin{array}{r}-2,903 \\
-66 \\
+512 \\
+87\end{array}$ \\
\hline
\end{tabular}

* Uric acid estimated in whole blood. 
late from plasma uric acid readings before and after treatment the total loss of body uric acid and to correlate this calculation with the actual excess observed in the urine. Such a calculation is shown in Table VI. Case 4 is excluded, as measurements of actual body weight were not taken. Where more than one estimation of circulating uric acid was made before treatment the mean has been taken. Such calculations require certain assumptions which need not be discussed here. Nevertheless, if the falls in plasma levels were greater than could be accounted for by the excess excretion, clearly a consistent discrepancy would appear. In Cases 2 and 5 the discrepancy is small, and in Case 3 slightly more uric acid was excreted than can be accounted for by the fall in plasma levels.

Only in Case 1 is there the sort of discrepancy which would be required to claim that the fall in plasma levels is greater than can be accounted for by the excess excretion. It was in this case, however, that an acute attack developed during the control period, with a rapid rise in blood levels. The excess excretion of uric acid during this period is more than enough to account for the change in total blood uric acid. Calculating the plasma volume as 0.051 body weight, and assuming that the fall is due to clearance by the kidneys, it would require an excess excretion of $243 \mathrm{mg}$. to reduce the level from 9.4 to $3 \mathrm{mg}$. per $100 \mathrm{ml}$. In the event $483 \mathrm{mg}$. was excreted in excess during the relevant period.

\section{Conclusions}

There are thus two possible effects exerted by phenylbutazone and influencing uric acid estimations: (1) uricosuric-while this is no more than a mild effect it is nevertheless sufficient to account for the observed fall in circulating urate levels; and (2) water retaining-this was sufficient to precipitate congestive heart failure in the one case in which a uricosuric effect was not observed.

It is suggested that the variable preponderance of uricosuric and water-retaining effects would account for the variable findings. Much further evidence is required to establish still a third effect, on uric acid metabolism itself; and the fact that uric acid excretion may be increased when phenylbutazone is administered is against such a possibility.

\section{Summary}

Four cases of gout and one control case were treated with phenylbutazone and the changes in plasma uric acid and urinary uric acid levels were studied.

The findings suggest that phenylbutazone has no more than a slight uricosuric effect. This may be neutralized if considerable water retention occurs at the same time.

No evidence was found that phenylbutazone has any direct effect on uric acid metabolism.

Cases 1 and 2 were under the care of Dr. W. S. C. Copeman, to whom I wish to record my gratitude. I am also grateful to Dr. T. Simpson for allowing me to study Case 3 .

\section{REFERENCES}

Benedict, J. D. Forsham, P. H., Roche. M., Soloway, S., and Stetten. De W. (1950). J. clin. Invest., 29, 1104.

Bowers, V. H. (1953). British Medical Journal, 1, 617

Engleman, E. P. (1952). Ann. rheum. Dis., 11, 297

Engleman, E. P. Williams, P. O. (1953). Lancet, 1957.

Kersley, G. D.. Watson, D., Bremner, J., and Millard, J. B. (1953). Ibid., 1, 95 .

Kidd. E. C., Boyce, K. C., and Freyberg, R. H. (1952). Ann. rheum. Dis., 11, 297. Kuzell. W. C., and Schaffarzick. R. W. (1952). Bull. rheum. Dis.. 3. 23. Smyth, C. J. (1953). Ibid., 152, 1106

Thorn, G. W.. Forsham, P. H., Frawley. T. F.. Hill. S. R., Roche. M. Staehelin, D., and Wilson, D. L. (1950). New Engl. J. Med., 242, 824.

British Schering Limited are now acting as sole distributors in the United Kingdom for the pharmaceutical specialty products of Schering A.G., of Berlin.

\section{DEATH FROM HYPERSENSITIVITY DUE TO PHENYLBUtazone}

\author{
BY \\ D. J. O'BRIEN, M.D. \\ AND
}

GEOFFREY STOREY, M.B., M.R.C.P., D.Phys.Med.

(From the Bernhard Baron Institute of Pathology and the Department of Physical Medicine, London Hospital)

Toxic effects of phenylbutazone have been described by a number of authors, and death has been ascribed mainly to agranulocytosis and to intestinal haemorrhage or perforation. A case is recorded in which death is attributed to a hypersensitivity reaction (in the course of phenylbutazone therapy).

\section{Case Report}

The patient was a man aged 73. Five years ago he began to have pain and stiffness in his hands and wrists. At first the pain was intermittent, but later it became continuous, until three years ago he had difficulty in moving his shoulders, elbows, wrists, and hands, and a diagnosis of rheumatoid arthritis was made. During the next year his knees and ankles were progressively, affected. Two years ago he was unable to walk. He then received a course of gold injections, which produced little improvement, but was followed by a rash.

Nine months ago he was admitted to the London Hospital. Examination at that time showed a wasted, anaemic man, with classical rheumatoid arthritis. Ulnar deviation and spindling of the fingers, and swelling of the metacarpophalangeal joints, were present, with little movement of the wrists. Movement at the elbows and shoulders was painful and limited. His knees were swollen and his ankles painful and limited in movement. Other systems were normal, except that his pulse showed frequent extrasystoles, with a soft systolic murmur at the apex, probably not organic, but related to the anaemia. His blood pressure was $150 / 60$. The erythrocyte sedimentation rate was $104 \mathrm{~mm}$. in one hour; haemoglobin $69 \%$; and leucocytes 8,700 per c.mm., with $74 \%$ polymorphonuclears. Rose's test was negative. He was treated by physical methods and with iron by mouth. After discharge, and five weeks before final admission, phenylbutazone was started, $0.2 \mathrm{~g}$. twice daily by mouth. This produced a marked subjective improvement, so that he was able to walk a mile. After five weeks' treatment, however, his - face began to swell, his eyes watered, and his mouth became dry and sore. He drank more fluids, but noticed that he passed scanty reddish-brown urine. $\mathrm{He}$ was short of breath, felt drowsy, and complained of a tingling sensation all over. Phenylbutazone was stopped, and he was admitted to hospital one week later.'

Examination showed that his arthritis had undergone no striking change. He was rather confused and slightly flushed, with puffiness of the face. His tongue was dry and furred, and there were three tender ulcers on the inside of the lower lip, the largest $0.5 \mathrm{~cm}$. in diameter. His pulse was regular, rate 120 , and his blood pressure was $120 / 80$. His apex beat was displaced outwards, and a third heart sound was heard at the apex but no murmurs. There were signs of fluid at both lung bases, and the liver was just palpable. The urine, which was orange-coloured, contained a cloud of albumin, and the deposit contained a few red cells and granular casts. An $x$-ray film of the chest showed cardiac enlargement, with hilar congestion and small bilateral pleural effusions, but the electrocardiogram showed only slight abnormalities-namely, ST depression in $\mathbf{C R}_{\mathbf{7}}$. The leucocytes were 6,000 per c.mm. (polymorphonuclears $77 \%$ ) and the blood urea was $38 \mathrm{mg}$. per $100 \mathrm{ml}$. 